
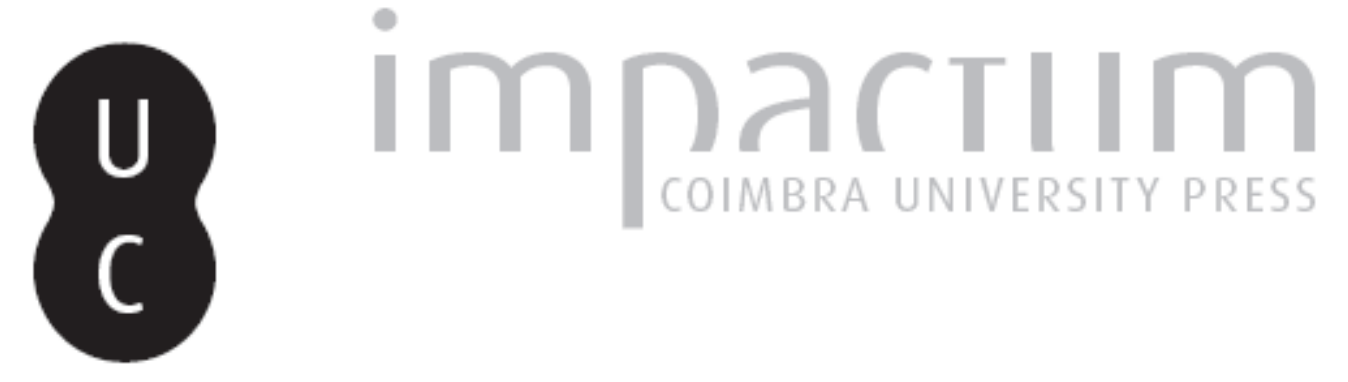

Hardship in the headlines: global poverty and neocolonialism in western news media Autor(es): $\quad$ Fox, Laura

Publicado por: Imprensa da Universidade de Coimbra

URL persistente:

URI:http://hdl.handle.net/10316.2/39638

DOI:

DOI:http://dx.doi.org/10.14195/2183-5462_29_12

Accessed : $\quad$ 26-Apr-2023 12:47:25

A navegação consulta e descarregamento dos títulos inseridos nas Bibliotecas Digitais UC Digitalis, UC Pombalina e UC Impactum, pressupõem a aceitação plena e sem reservas dos Termos e Condições de Uso destas Bibliotecas Digitais, disponíveis em https://digitalis.uc.pt/pt-pt/termos.

Conforme exposto nos referidos Termos e Condições de Uso, o descarregamento de títulos de acesso restrito requer uma licença válida de autorização devendo o utilizador aceder ao(s) documento(s) a partir de um endereço de IP da instituição detentora da supramencionada licença.

Ao utilizador é apenas permitido o descarregamento para uso pessoal, pelo que o emprego do(s) título(s) descarregado(s) para outro fim, designadamente comercial, carece de autorização do respetivo autor ou editor da obra.

Na medida em que todas as obras da UC Digitalis se encontram protegidas pelo Código do Direito de Autor e Direitos Conexos e demais legislação aplicável, toda a cópia, parcial ou total, deste documento, nos casos em que é legalmente admitida, deverá conter ou fazer-se acompanhar por este aviso. 


\section{Media Jornalismo}

\section{MÉDIA E COLONIALISMO(S)}




\title{
HARDSHIP IN THE HEADLINES: GLOBAL POVERTY AND NEOCOLONIALISM IN WESTERN NEWS MEDIA
}

\section{LAURA FOX}

YORK UNIVERSITY AND RYERSON UNIVERSITY/ JOINT GRADUATE PROGRAM IN COM-

\author{
MUNICATION AND CULTURE \\ TORONTO, ON M3J IP3 CANADA \\ ANNLAURAFOX@GMAIL.COM
}

\begin{abstract}
Poverty is one of the most significant issues facing the world today. Although Western news media often report on the manifestations of poverty-famine, overcrowding, epidemics, or natural disasters - they rarely reflect the political, economic, and ideological structures that have directly caused and continue to exacerbate it on a global scale. This article argues that Western news media communicate global poverty, as a pressing issue, but ultimately fail to point out underlying causes or suggest any changes to the status quo. This fosters an understanding of poverty as a series of events, rather than the lived daily experience of many. This article, therefore, investigates the structures of neocolonial capitalism and neoliberal ideologies that gained momentum in the $20^{\text {th }}$ century and continue to frame the content of news media today. Discussing the concepts of 'compassion fatigue' and Anthony Downs' 'issue-attention cycle', this article is a normative analysis of news media, exploring new ways to educate citizens on the global political economy. Drawing on the work of Lauren Berlant and Robert McChesney, this article ultimately discusses new ways of communicating poverty, which will require an acknowledgement of neocolonialism and a rethinking of crisis as lived daily experience.
\end{abstract}

\section{KeYWORDS}

Poverty, media, news, journalism, global, international, political, neocolonialism, communication, development

\section{INTRODUCTION}

Poverty is one of the most significant issues facing the world today. The United Nations (UN) listed it as the first of seventeen Sustainable Development Goals (SDGs) defined in September 2015 as a replacement for the previous list of Millennium Development Goals (MDGs) (UNDP, 2015). However, poverty is not a default issue that simply exists as a global phenomenon. Rather, it has been a result of capitalist and neoliberal ideologies that have existed for decades and that continue to structure the global political economy. This failure to acknowledge underlying causes has given birth to new forms of colonialism, or 'neocolonialism', which continue to benefit a few at the expense of the rest. The term 'neocolonialism', as first defined by former president of Ghana, Kwame Nkumrah, refers to the perpetuation of a country's 
cultural and economic control over their previously colonized states, despite an official withdrawal of political control (1965). Nkumrah was referring specifically to Europe's continued control in Africa after the decolonization of the continent in the late $20^{\text {th }}$ century (1965). However, the concept as such can now be expanded to refer to control by industrialized nations of the Global West/North over developing nations of the Global South. If the UN is serious about eradicating poverty in the next 15 years, as the SDGs suggest, the global institution must focus on changing the ideological structures that produce and maintain poverty, rather than simply recognizing its manifestations (Lugo-Ocando, 2015). Although news media and communication cannot change these underlying structures alone, they can work to better reflect the processes of neocolonialism, and direct the attentions of audiences to the political, economic, and ideological causes of poverty.

This article proposes a broad look at the structures of neocolonial capitalism and the neoliberal ideologies that gained momentum in the latter half of the $20^{\text {th }}$ century, and which continue to frame the content of news media today. It examines the ways in which global news media currently communicate poverty, showing it as a series of events rather than a lived daily experience, and ultimately failing to suggest any changes to the status quo. For the purposes of this article, the term 'poverty' is considered to mean absolute or extreme poverty on an international level. It is important to note that varying levels of poverty exist and it is often considered to be a national issue; poverty exists within developed or industrialized nations as well. However, this article takes a global perspective on poverty, considering the international statistic of 836 million people who still live on less than $\$ 1.25$ a day (UNDP, 2015), the majority of whom live in Southern Asia and Sub-Saharan Africa (UNGA, 2015). It is also important to note that the term 'global news media' refers here to media producing stories and information in the Global North and/or the West, a perspective borrowed from Jairo Lugo-Ocando in his critique on global journalism:

These are the news media outlets that are based in those countries with sufficient wealth and power to influence the most powerful elites and to mobilize people within those countries; this group of nations is often called the West, but also includes countries such as Australia or Japan (2015: 6).

A focus on Western news media provides helpful reflections on the system of global hegemony that has persisted since the Second World War, in which the West has been and continues to be the most powerful and influential region. This is based largely on the privileged position of countries such as the United States within the global institutions of the UN, the World Bank (WB), the International Monetary Fund (IMF), or the World Trade Organization (WTO) (Reinert, 2007). News media may differ slightly from nation to nation, but the content is similar, if not the same, everywhere (McChesney, 2014; Lugo-Ocando, 2015). It becomes apparent that content and information about the issue is shaped by the current global political economy, which, in turn, shapes the general public's understanding of the issue.

Based on this understanding of capitalist and neoliberal frameworks, there is a need to explore new ways of comprehending poverty and the ways in which news media can contribute towards the goal of alleviating the global issue. In a world of 
rapid globalization and technological change, "the media is the number one department of education" (McChesney, 2014:158). This article, therefore, questions the content and information that news media convey, not through an empirical investigation, but rather through an extensive review of literature and theory. The result is a normative analysis of the importance of news media in framing the global issue of poverty and directing audience attention to overarching ideologies that structure the current global order. Drawing on the work of Lauren Berlant and Robert McChesney, it becomes clear that new ways of communicating poverty might require a rethinking of trauma and crisis as a way of life, rather than a set of events in history.

\section{Poverty, the issue-attention cycle, and compassion fatigue}

Global news media coverage usually concentrates on manifestations of poverty as events that happened in one instance, rather than pieces of the larger puzzle of poverty that already exists as a way of life. An example of this is the 2014 outbreak of Ebola in West Africa, which was the largest in history, affecting multiple countries in the region (CDC, 2015). For a period of time, the outbreak dominated headlines and the world was made aware of just how serious the epidemic had become. The outbreak has caused upwards of 11,000 deaths since it began in 2014 (WHO, 2015a). Extensive global coverage conceptualized the outbreak as a specific event that occurred in West Africa and then began to spread globally. However, much of this coverage failed to reflect the systemic poverty that was already in place in the region, which exacerbated the outbreak and made it more difficult to contain. More in-depth analyses of the situation noted the poorly developed healthcare systems and lack of education about health practices in the developing countries of Sierra Leone, Liberia, and Guinea, which were hit hardest by the epidemic (WHO, 2015a).

Since its initial outbreak and spread in 2014, Ebola seems to have lost its spotlight in news coverage. Indeed, news media eventually stopped reporting on it partially because the disease has since been mostly contained and there is now less likeliness of widespread transmission (CDC, 2015; WHO, 2015a). However, it is also because the outbreak as an event had to, at some point, be considered 'over' and thus no longer newsworthy. During a recent second outbreak of Ebola in 2016 (WHO, 2016), news of the disease hit headlines briefly again, as another event to be covered. Meanwhile, Sierra Leone, Liberia, and Guinea still remain in the lowest income grouping of the WHO's most recent report on health statistics (WHO, 2015b), regardless of whether the West is paying attention or not. This means poor quality healthcare still remains a part of daily life for many in the region (WHO, 2015a), making it easy for disease to spread.

Indeed this manifestation of poverty, along with many others, is subject to what Anthony Downs terms the 'issue-attention cycle'. The concept is closely linked to McCombs and Shaw's agenda setting theory, whereby mass media is used to decide the order of importance of issues, directing the general public's attention to certain issues over others. In the issue-attention cycle, however, Downs notes, an issue "suddenly leaps into prominence, remains there for a short time, and then-though still largely unresolved — gradually fades from the centre of public attention" (1972: 38). This is perhaps most notable in reports of large natural disasters, such as the 2010 earthquake in Haiti, the gravity of which was only made worse by the poor 
living conditions and weak infrastructure that already existed in the country. Other manifestations of poverty, such as famine or overpopulation, are rarely reported by news media unless they reach a particularly dismal level.

Manifestations such as these are rarely reflected upon as part of a continuous cycle. In addition to Downs' concept of the issue-attention cycle, this also results in the development of 'regimes of pity', or "common spaces between spectators in the West and those who suffer" (Lugo-Ocando, 2015, p. 2). A common assumption is that the emotions connecting Western viewers to those in extreme poverty could serve as motivation for people in wealthy nations to mobilize and push for policy change. More often than not, however, the repetitive nature of coverage on poverty leads to 'compassion fatigue', in which the public becomes tired and somewhat desensitized to emotions that could have perhaps been tapped into previously (Lugo-Ocando, 2015).

Global news media cannot continue to communicate manifestations of poverty as passing events, but rather must reflect a need for global structural change. Former Irish minister of Foreign Affairs and Trade, Sean MacBride, understood this a few decades ago, and it still rings true today:

The international media frequently provide striking reports of famines, floods, epidemics and other disasters suffered by developing countries, and thereby help to prompt government and private organizations to launch relief and assistance schemes. However, the media should go beyond the state of promoting initial relief and reconstruction, they have to contribute to development and change as such; they also have to analyze the causes (1980: 179).

What were the causes of poverty to which MacBride was referring? In order to establish why news media communicate poverty as events, it is helpful to examine more closely the structural causes of poverty and why it exists in the form it does today.

\section{Neoliberalism and neocolonialism in global governance}

Like most global phenomena, news media are situated within a framework of capitalist structures and neoliberal ideologies that have prevailed since the establishment of the 'international community' after the Second World War (Reinert, 2007; Lugo-Ocando, 2015). However, these structures and ideologies can be traced back even further to the $19^{\text {th }}$ century socioeconomic theories of Karl Marx and Friedrich Engels. In their manuscripts in The Germany Ideology, originally written in 1846, Marx and Engels included their essay "The Ruling Class and the Ruling Ideas", in which they famously argue that the prevailing ideas of a society are not formed separately from the class system, but are rather controlled by the ruling class and work in their favour: "the class which is the ruling material force of society is at the same time its ruling intellectual force" (2012: 31). This was a significant work, as it demonstrated the role of ideology in society, and questioned who creates and controls the dominant ideologies that frame daily life. As Marx and Engels suggest, the ruling class has power and influence over the production and distribution of ideas, as well as the ability to project these ideas as 'universal', which has detrimental effects on 
how the events of history are communicated and recorded (2012). When applied on a global scale, this notion of the ruling class is at the heart of neocolonialism today.

Much later, in 1988, Edward Herman and Noam Chomsky put forth another interpretation of this concept in their essay "A Propaganda Model", in which they suggest the mass media and its ability to communicate messages to large audiences "function and amuse, entertain and inform, and to inculcate individuals with the values, beliefs, and codes of behaviour that will integrate them into the institutional structures of the larger society" (2012: 204). Herman and Chomsky in many ways draw on the same notions of the ruling class using its power over media and communication to influence the general public. However, Herman and Chomsky introduced their propaganda model during the 1980s, a much later period in history than that of Marx and Engels, and a time in which capitalism and, specifically, neoliberal ideology was gaining momentum.

At this time, the end of the Cold War and "the socialist experiment meant that many in the West stopped talking about poverty in a serious way" (Lugo-Ocando, 2015). After the collapse of the Soviet Union, the late $20^{\text {th }}$ century saw a vast reduction of foreign aid, as well as sweeping policies for deregulation, privatization, and liberalization of markets. The WB and the IMF also attempted to remedy debt crises in much of the developing world by introducing their Structural Adjustment Programs (SAPs) to regions such as Latin America, which were asked to introduce new economic policies that were more oriented towards a free market (Lugo-Ocando, 2015; Reinert, 2007). The SAPs have since been widely criticized for refusing to offer any choice to nations looking for loans. These programs only widened the economic gap between borrowing countries and the countries with the most power in these global institutions, which were the hegemonic nations of the West, namely the United States. In fact, the Western assumption that economic harmony was to be achieved by a laissez-faire attitude towards the global market would become extremely problematic, and many populations now still find themselves in states of cyclical poverty as a result (Reinert, 2007). These economic actions allowed for Western nations to further assert their control. Thus, despite the many instances of decolonization that occurred in the late $20^{\text {th }}$ century, through which many nations declared independence, new forms of colonialism manifested themselves through these economic decisions.

Herman and Chomsky suggest that mass media and communication also maintain these colonial powers and divisions between 'have' and 'have-not' nations in what they call 'systemic propaganda': "A propaganda model focuses on the inequality of wealth and power and its multi-level effects on mass media interests and choices" (2012: 204). They were referring largely to mass media and the distribution of ideas pertaining to domestic interests, but the propaganda model is still quite fitting when applied to structures of hegemonic power on a global level today. Much has changed in the past few decades in terms of technology and globalization, but these theories still very much ring true in the context of the $21^{\text {st }}$ century. In fact, Jaime Lugo-Ocando applies this same thinking to current news media, suggesting that there is a need now more than ever for a more globalized approach: "media globalization has brought the world closer, while simultaneously deepening the gap between social classes" (2015: 2). 
Robert McChesney's contemporary critiques on American media also echo these sentiments towards power imbalances: "The 1 percent... tend to have access to the information they need to run the world to their benefit" (2014: 231). Despite a more globalized and digitally connected world, McChesney claims that the work of American reporters today is still very much framed by neocolonialism in the global political economy $(2004 ;$ 2014). He even notes that it is exactly because of this that the academic field of 'the political economy of communication' has emerged as an attempt to "[examine] how the capitalist structure of communication industries shapes media content" and, particularly, "how media 'depoliticizes' people, and thereby entrenches the privileges of those at the top" (2014: 188-9).

Although McChesney's critique is focused on media specifically in the United States, a more globalized world means more global issues. He suggests that the same problems can also be found elsewhere: "In every country around the world, people are battling with these issues, and they're really the same issues everywhere" (2014: 153). Indeed, the same capitalist and neoliberal ideologies that have long kept political and economic power in Western hands continue to frame the content of news media. This is particularly true of the type of information distributed about poverty, which tends to oversimplify the issue by conveying it as a series of events happening somewhere else in the world.

\section{ChANGing THE POVERTY NARRATIVE}

In order to truly tackle global poverty, there needs to be a shift in public opinion, particularly within Western nations. When poverty is illustrated by its manifestations, the concept of systemic inequality gets massively overlooked. Furthermore, as news reporting is assumed to possess the element of objectivity, it often serves to support and uphold the ideologies that are already in place, as Lugo-Ocando explains:

In this worldview, poverty is rarely presented as a rational phenomenon that follows the logic of inequality. There are very few occasions when the public is told that the reason why so many have so little is because so few have accumulated so much... In reality, most journalists and news editors operate within specific ideological categories that define not only the way poverty is constructed in the news room but also the narratives that frame it as a news item $(2015$, p. 4).

To achieve the UN's goal of alleviating poverty, there needs to be a restructuring of the current global political economy. News media cannot be the sole means by which this restructuring happens, but they can play a crucial role in it by working to "focus attention, point out opportunities, attack indifferences... and influence the climate of opinion... This applies both to the mobilization of public opinion in developing countries and to the spread of greater understanding in the developed" (MacBride, 1980: 179).

This greater understanding in the developed world can only be achieved by a fundamental shift in the reporting of poverty as manifestations or events to one in which poverty is considered to be a way of life. In her book Cruel Optimism, Lauren Berlant investigates how societies today often get in the way of their own happiness, as the things they desire also act as obstacles to their 'flourishing'. She ex- 
plores what happens when humanity is faced with the realization that only a few are able to attain what for decades has been considered to be 'the good life' (2008; 2011): "Cruel optimism names a relation of attachment to comprised conditions of possibility whose realization is discovered either to be impossible, sheer fantasy, or too possible, and toxic" (2008: 33). Berlant claims that living or surviving requires a form of attachment to the object world, which she defines as "a cluster of promises" involving other people, ideas, smells, flowers, etc. It is the ways in which one is attached to these objects, however, that involve affect and emotion and that make this attachment political (2008; 2011).

A central theme for Berlant is trauma theory and the question of how one is able to come to terms with the idea of crisis. Berlant suggests that, in the latter half of the $20^{\text {th }}$ century, the world redefined itself in relation to the traumatic events of the Holocaust and the Second World War and "for the past few decades, trauma theory has provided the main way of periodizing any crisis-shaped historical present" (2011: 54). However, she presents new ways of interpreting the present, that is, not by considering trauma simply as a series of events in history, but rather as lived everyday experience. 'Crisis ordinariness' is her term for the 'misrecognition' of trauma in everyday life:

A traumatic event is simply an event that has the capacity to induce trauma. My claim is that most such happenings that force people to adapt to an unfolding change are better described by a notion of systemic crisis or 'crisis ordinariness' and followed out with an eye to seeing how the affective impact takes form, becomes mediated. Crisis is not exceptional to history or consciousness but a process embedded in the ordinary that unfolds in stories about navigating what's overwhelming (2011: 10).

Berlant's take on crisis as a process or ongoing experience is a helpful mindset when thinking about how to change representations of poverty in news media. One must consider poverty as a type of trauma or crisis not exceptional to history, but in everyday life. By changing the ways in which poverty is communicated, media can better convey the issue to general publics, who then affectively process it. It is, after all, the memory's affective work that defines what constitutes the present (2011).

Berlant proposes a need for change and the construction of a new world or, rather, a new model for 'the good life' that would benefit more of humanity. This requires the recognition of attachment and, ultimately, the loss of attachment to the object world. Recognizing and accepting this loss of 'the good life' would then open up a space for opposition to and emancipation from the status quo (2008; 2011). This recognition is exactly what news media can and should provide. They need to stimulate recognition of the current ideologies that structure the world and result in poverty in the first place. In line with Berlant's conceptions of the 'historical present', McChesney also suggests that the job of media is to "understand the present and put it in historical perspective" (2014: 17). This means instead of providing simple explanations for the manifestations of poverty, news media must go further to reflect the situation of these occurrences in the historical timeline of poverty. This is how news media can contribute to the general public's recognition of ideological structures and spark a genuine desire for social change. 
An example of this concept of recognition can be found in the Occupy Movement of 2011, a protest opposing global systems of social and economic inequality. It began in the Wall Street financial district of New York, spread to other cities in the United States, and eventually gained worldwide attention and support. Occupy was a manifestation of the public's recognition and subsequent reaction to the loss of the object, or the fantasy of 'the good life'. Although the success of Occupy has since been debated, it presents an example of the space for change that recognition can create (Berlant, 2008; 2011).

One way that news media can work to reflect the global ideologies in place is to showcase movements of opposition to them, such as Occupy, which demonstrated the fact that generations today have become much more critical of neocolonialism and the capitalist political economy than their predecessors (McChesney, 2014). As McChesney suggests, however, media coverage of Occupy in the United States quickly became scarce and gave way to pessimism about the possibility of any real social change:

Such uprisings had not been seen in the United States for decades, maybe generations. A sleeping giant, it seemed, had been awakened and aroused, its power harnessed by young people... Yet, especially after 2011, the optimism generated by these movements had dissipated, and the most arresting sentiment I encountered as I traveled the nation was one of tremendous pessimism about the possibility of progressive social change (2014: 15).

Furthermore, McChesney suggests that there are few other political movements normally covered by the mainstream media: "because there [are] almost no mainstream media coverage of these grassroots developments, people [assume] they [do] not exist" (2014: 16). Although news media cannot change the underlying structures of capitalism alone, they can cover smaller movements similar to Occupy that directly oppose these structures. News media should be regularly spotlighting the issue of poverty and active efforts to oppose the ideologies that favour a small population of the world at the expense of the majority. As MacBride argues, "consciences should not be dormant from one emergency to the next" (1980: 179).

Of course, it is also important to consider the role of digital media and the Internet in shifting public opinion and understandings of poverty. Critiques of communication and the spreading of ideas were previously directed primarily at mass media, as in the works of Marx and Engels, Herman and Chomsky, and other thinkers such as Theodor W. Adorno and Max Horkheimer (2012) and the rest of the Frankfurt School. However, it is clear that in the $21^{\text {st }}$ century, mass media such as television and newspapers are not the only channels for communicating information or current events. The Internet has opened up a space not only for digitizing news, but also for the general public to share their own thoughts and opinions through blogs, opinion pieces, and social media. There is no doubt that the circulation of information about poverty and its manifestations at the micro-level of Internet users is significant in the affective processes of how one understands it as a global issue.

Although the micro-level is significant, however, it is only a small part in what must be a broader movement for media reform, particularly in the United States, 
but on a global level as well (McChesney, 2004; 2014). The micro-level referred to here also includes community journalists on the Internet or in other media, such as television or radio. It is very important to have news circulating from the ground-up, which the Internet enables. In order to fully grasp the issue of poverty and to alleviate it on a global level, however, mainstream news media must escape the ideological boundaries of the global political economy in order to better serve the public in terms of the information that they make available. As McChesney points out, the Internet and the newly perceived power of the user in the digital age is often put forth by mainstream media as an argument as to why they need to continue to be subsidized without any changes to the status quo:

The Internet is this enormous propaganda device employed by the industry and their PR people and their lackeys. Every time they want to do anything, they wave the Internet flag, and say, 'Well, there is always new content on the Internet, so you've got to do whatever we want. Everything's changing; you can't regulate it, you have to keep giving us subsidies on our terms, you have to do whatever we tell you because of the Internet"... argument number 1-A that's used by the industry at every turn in the United States (2014, p. 155).

McChesney calls for media reform in the United States, but suggests that his critiques of the American media are simply magnified at a global level. He even suggests that the next step for media reform would require a global summit to pressure leaders and institutions to better serve the public (2014).

\section{FinAL REMARKS: MOVING TOWARDS A NEW WORLD}

The scholars mentioned here all seek to transform the global political economy into one that best serves the global population, rather than the current one, which benefits only a select few. Berlant suggests that a key first step in creating a new version of 'the good life' and a new world in which everyone would want to live is to recognize the objects to which one is attached and the political dimension of this affective attachment. McChesney's idea of a new world is what he terms the 'post-capitalist democracy", or "a society... that directly addresses the ways that really existing capitalism is inimical to democracy, human freedom, and ecological sustainability"; he points out that this is, indeed, what Marx meant by his concept of socialism (2014: 21). The UN has conceptualized the new world as one in which there is equality for all, and the steps to creating it are outlined in the form of the SDGs.

What is the role of news media in creating this new world? Although they can perhaps not be the sole influencers in creating change, they can act as better directors of attention, making audiences take notice of the capitalist ideologies that frame daily life around the world. First and foremost, news media can foster new conceptions of poverty not by simply reporting on its manifestations, but by instead reflecting the structures of the global political economy that create poverty as a lived, everyday experience. By additionally making room for stories about grassroots movements that challenge the status quo, news media can shine a light on the neocolonialism that continues to dictate the global order. This is how news media can actively contribute to creating social change. 


\section{References}

Berlant, L. (2008). Cruel Optimism: On Marx, Loss and the Senses. New Formations, 63, 33-52. -. (2011). Cruel Optimism. Durham; London: Duke University Press.

Centers for Disease Control and Prevention (CDC). (2015). 2014 Ebola Outbreak in West Africa. Accessed December 6, 2015.Retrieved from: http://www.cdc.gov/vhf/ebola/ outbreaks/2014-west-africa/

Downs, A. (1972). Up and Down With Ecology - the "Issue-Attention Cycle". Public Interest, 28, 38-50. Washington, DC: National Affairs, Inc.

Herman, E. \& Chomsky, N. (2012). A Propaganda Model. In D M. Kellner \& M. G. Durham (Eds.) Media and Cultural Studies: Keyworks (2 ${ }^{\text {nd }}$ ed.) (204-31). Chichester, UK: Wiley-Blackwell. Horkheimer, M. \& Adorno, T. W. (2012). The Culture Industry: Enlightenment as Mass Deception. In D M. Kellner \& M. G. Durham (Eds.) Media and Cultural Studies: Keyworks ( $2^{\text {nd }}$ ed.) 53-75. Chichester, UK: Wiley-Blackwell.

Lugo-Ocando, J. (2015). Blaming the Victim: How Global Journalism Fails Those in Poverty. London: Pluto Press.

MacBride, S. (1980). Many Voices, One World: Towards a New, More Just, and More Efficient World Information and Communication Order. New York: UNESCO.

Marx, K. \& Engels, F. (2012). The Ruling Class and the Ruling Ideas. In D M. Kellner \& M. G. Durham (Eds.) Media and Cultural Studies: Keyworks (2nd ed.) (31-3). Chichester, UK: Wiley-Blackwell.

McChesney, R. W. (2004). The Problem of the Media: US Communication Politics in the 21st Century. New York: Monthly Review Press.

. (2014). Blowing the Roof of the Twenty-First Century: Media, Politics, and the Struggle for Post-Capitalist Democracy. New York: Monthly Review Press.

McCombs, M. \& Shaw, D. (1972). The Agenda-Setting Function of Mass Media. Public Opinion Quarterly, 36 (2), 176-187.

Nkrumah, K. (1965). Neo-Colonialism, the Last Stage of Imperialism. London: Nelson \& Sons, Ltd. Reinert, E. S. (2007). How Rich Countries Got Rich... and Why Poor Countries Stay Poor. London: Constable \& Robinson, Ltd.

United Nations Development Programme (UNDP). (2015). Goal 1: No poverty. Accessed December 6, 2015. Retrieved from: http://www.undp.org/content/undp/en/home/mdgoverview/post-2015 development-agenda/goal-1/

United Nations General Assembly (UNGA). (2015). Resolution adopted by the General Assembly on September 25, 2015: Transforming our world: the 2030 Agenda for Sustainable Development. Retrieved from: http://www.un.org/ga/search/view_doc.asp?symbol=A/RES/70/1\&Lang=E World Health Organization (WHO). (2015a). Ebola virus disease outbreak. Accessed June 8, 2016. Retrieved from: http://www.who.int/csr/disease/ebola/en/

. (2015b). World Health Statistics 2015. Global Health Observatory (GHO) data. Accessed June 8, 2016. Retrieved from:

http://www.who.int/gho/publications/world_health_statistics/2015/en/

-. (2016). Liberia and Guinea step up coordination to stem new cases of Ebola.

Accessed June 8, 2016. Retrieved from: http://apps.who.int/csr/disease/ebola/liberia-guinea-flareups-update/en/index.html 